\title{
Phytochemistry and microscopy of Tapinanthus dodoneifolius (DC) (Danser) (Santalales: Loranthaceae) (African mistletoes) from guava, rubber and orange host trees
}

\section{MacDonald Idu*, Oghale Ovuakporie-Uvo and Martin John Nwaokolo}

Department of Plant Biology and Biotechnology, University of Benin, PMB 1154, Benin City, Nigeria.*Email: mcdonald.idu@gmail.com.

\begin{abstract}
Qualitative and quantitative phytochemistry, micro and macro-elements and microscopy of Tapinanthus dodoneifolius (DC) (Danser) (Santalales: Loranthaceae) collected from guava (Psidum guajava L.), rubber (Hivea brasilensis Müll. Arg.) and orange (Citrus sinensis (L) Osbeck.) trees was carried out. This was done with the purpose of comparing their pharmacological and biological contents. Qualitative and quantitative phytochemical screenings were done using described methods. Microscopic study was done with the aid of a light microscope and photomicrographs were taken using a 14-mega pixel Sony cyber-shot. Result of phytochemical analysis showed the presence of oxalate, phytate, saponin, alkaloid, glycoside and tannin in African mistletoes. These phytochemicals were present in proportions that varied with their hosts. The microscopic observation showed no significant differences in the internal structures of mistletoes from the three host trees. From this present study, more differences were observed in the phytochemistry than the anatomy of the mistletoes understudied.
\end{abstract}

Keywords: African mistletoes; Phytochemistry; Microscopy; Micro and macro-elements.

\section{Introduction}

Plants serve various purposes in the world today. Their usefulness can be in form of food, shelter, textile, religious practices and medicines (Fabeku, 2006). Records of indigenous knowledge from various parts of the world illustrate an age long tradition of plants being a major bioresource base for health care (Ataman et al., 2006; Idu et al., 2006). African mistletoe
Received

February 2, 2016

Accepted

May 12, 2016

Released

June 30, 2016

Open Acess

Full Text Article

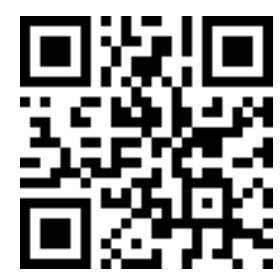

ORCID
0000-0002- 5082-1988
MacDonald Idu
0000-0002-1394-5658
Oghale Ovuakporie-
Uvo
0000-0001-6795-8481
Martin John Nwaokolo
Tapinanthus dodoneifolius (DC) (Danser) belonging to the Family Loranthaceae, is a plant of numerous ethnomedicinal relevance (Judd et al., 2002; Uthman et al., 2015). A wide variety of pharmacological effects have been studied on varieties of mistletoe and have been reported to be antidiabetic (Orhan et al., 2005; Shahaboddin et al., 2011), vasodilator (Tenorio-Lopez et al., 2005; 2006), sedative, antiepileptic, antipsychotic (Gupta et al., 2012), 
antihypertensive (Ofem et al., 2007), antiinflammatory, immunostimulant (Lavastre et al., 2004), antimutagenic (Hong and Lyu, 2012), anticancer (Burger et al., 2001; Cetin and Ozcelik, 2007; Sabova et al., 2010) as well as antioxidant activities (Orhan et al., 2005; Shahaboddin et al., 2011).

African mistletoe (Tapinanthus dodoneifolius (DC) Danser) called 'Kauchi' in Hausa is a hemi-plant parasite used ethnomedicinally by the Hausa and the Fulani Tribes of Northern Nigeria as a remedy for several human and animal ailments that include stomach ache, diarrhoea, dysentery, wound and cancer (Deeni and Sadiq, 2002). However, the growth of mistletoe on different kinds of plants exhibit disease curing specificity. For example, Ekhaise et al. (2010) observed that mistletoe grown on guava, kolanuts and citrus are specific for curing diseases like cancer, hypertension, nervousness and insomnia, while those grown on cocoa are best used for curing diabetes. The usefulness of vegetative and anatomical features in the bio-systemic consideration of various taxa have been reported by Edeoge and Eboka (2000) and Edeoge and Ikem (2001). Also, the phytochemical profile and bioactivity of mistletoe have been reported to depend on the host trees (Luczkiewicz et al., 2001; Vicas et al., 2011).

This study is aimed at (a) investigating the secondary metabolites present in the mistletoes leaf harvested from rubbber, guava and orange trees, (b) investigate the micro and macro-elements present in the mistletoe leaves from each host tree and (c) examine the microscopic characters of the leaves and stems of the mistletoes harvested from the host trees.

\section{Materials and methods}

\section{Sample collection}

The leaf and stem of mistletoes were collected from Auchi Edo State, Nigeria in May 2015. The mistletoes were identified botanically by the Herbarium staff, Department of Plant Biology and Biotechnology, University of Benin, Benin City, Nigeria.

\section{Preparation of plant material}

The plant materials were cleared of debris and air dried for three days. After which they were kept in the oven for further drying at $40{ }^{\circ} \mathrm{C}$. The dried plant materials were ground to powder using a mechanical grinder. Each of these ground powder materials was stored in moisture free airtight containers until ready for use.

\section{Phytochemistry analysis}

Phytochemistry was done following the standard methods described by Ochuko and Obadoni (2001), Official Methods of Analysis of Association of Official Analytical Chemist International (Cunniff, 2005), and Sofowora (2008).

\section{elements}

\section{Analysis for micro and macro-}

These were done following reference methods described by Official Methods of Analysis of Association of Official Analytical Chemist International (Cunniff, 2005) and Idu et al. (2014).

\section{Microscopy}

A young fresh stem and leaf of mistletoe were collected for microscopy. The structures present in the leaf and stem were observed with special interest on the epidermal cells and the shape of the microscopic characters using methods described by Bhandari and Mukhopadhyay (2001). Internal structures were viewed using a compound light microscope and photographed at a magnification of $\mathrm{x} 40$ using a 14-mega pixel Sony cyber-shot camera.

\section{Statistical analysis}

Data were presented as Mean \pm Standard Error of Mean using Microsoft Excel computer software (2016 version). Where $\mathrm{n}$, which represents the number of replicates per test was equal to three.

\section{Results} analysis)

Phytochemistry (qualitative

Qualitative analyses of mistletoes from three host plants, guava, rubber and 
orange trees, was done. Results show that all of the mistletoes contain phytate, saponin, alkaloids, glycosides and tannins (Table 1).

Results of quantitative phytochemistry studies shows that mistletoe leaves got from rubber tree contain higher deposits of oxalate $(210.65 \pm 0.03)$, phytate $(317.65$ $\pm 0.03)$, saponin $(44.38 \pm 0.01)$, alkaloids $(14.91 \pm 0.05)$ and glycosides $(8.62 \pm 0.00)$ compared to guava and orange trees. However, mistletoe leaves from guava tree had high tannin content $(106.52 \pm 0.05)$ (Table 2).

Quantitative analysis of macroelements, sodium $(\mathrm{Na})$, potassium $(\mathrm{K})$, calcium (Ca), and magnesium (Mg) on mistletoes harvested from guava, rubber and orange trees show that mistletoe from guava tree are richer in $\mathrm{Na}(243.86 \mathrm{mg} / \mathrm{kg})$, $\mathrm{K}(265.74 \mathrm{mg} / \mathrm{kg})$, Ca $(428.35 \mathrm{mg} / \mathrm{kg})$ and $\mathrm{Mg}(586.91 \mathrm{mg} / \mathrm{kg})$ than the two other host trees. Micro-elements, Fe $(525.38 \mathrm{mg} / \mathrm{kg})$ was found most abundantly present in mistletoes from orange tree. Zn (321.68 $\mathrm{mg} / \mathrm{kg}$ ) was most present in mistletoes from guava tree while $\mathrm{Mn}(100.08 \mathrm{mg} / \mathrm{kg})$ was most abundantly present in mistletoes got from rubber tree (Table 3).

Microscopy of stem and leaf of mistletoe viewed under a light microscope are shown on Figures 1 and 2. The photomicrographs show the epidermis, cortex, palisade cells, spongy cells, vascular bundles, phloem, xylem of leaves and stem of mistletoes harvested from guava and orange trees.

Table 1. Qualitative analysis of phytochemical constituents of mistletoe from different hosts (n $=3$ replicates).

\begin{tabular}{llllllllll}
\hline Secondary metabolites & \multicolumn{3}{l}{ Guava mistletoe } & \multicolumn{3}{l}{ Rubber mistletoe } & \multicolumn{3}{c}{ Orange mistletoe } \\
\hline Oxalate & - & - & + & + & + & + & - & - & + \\
Phytate & + & + & + & + & + & + & + & + & + \\
Saponin & + & + & + & + & + & + & + & + & + \\
Alkaloid & + & + & + & + & + & + & + & + & + \\
Glycoside & + & + & + & + & + & + & + & + & + \\
Tannin & + & + & + & + & + & + & + & + & + \\
Flavonoid & + & - & - & + & - & - & + & - & - \\
\hline
\end{tabular}

+ present; - absent.

Table 2. Quantitative analysis of phytochemical constituents of mistletoe from different hosts, guava, rubber and orange trees ( $\mathrm{n}=3$ replicates).

\begin{tabular}{lccc}
\hline Secondary Metabolites & $\begin{array}{c}\text { Guava's mistletoe leaf } \\
\text { (mg/100g) }\end{array}$ & $\begin{array}{c}\text { Rubber mistletoe leaf } \\
\text { (mg/100g) }\end{array}$ & $\begin{array}{c}\text { Orange's mistletoe } \\
\text { leaf (mg /100g) }\end{array}$ \\
\hline Oxalate & $18.74 \pm 0.01$ & $210.65 \pm 0.03$ & $123.53 \pm 0.02$ \\
Phytate & $285.31 \pm 0.03$ & $317.65 \pm 0.03$ & $277.82 \pm 0.04$ \\
Saponin & $23.51 \pm 0.02$ & $44.38 \pm 0.01$ & $21.44 \pm 0.03$ \\
Alkaloid & $7.08 \pm 0.10$ & $14.91 \pm 0.05$ & $5.76 \pm 0.08$ \\
Glycoside & $3.65 \pm 0.01$ & $8.62 \pm 0.00$ & $3.65 \pm 0.01$ \\
Tannin & $106.52 \pm 0.05$ & $77.93 \pm 0.02$ & $58.84 \pm 0.04$ \\
\hline
\end{tabular}

Values are Mean \pm SEM. 
Table 3. Quantitative analysis of macro and micro-elements in mistletoes from different host plants ( $\mathrm{n}=3$ replicates $)$.

\begin{tabular}{llccc}
\hline Elements & $\begin{array}{c}\text { Guava's mistletoe leaf } \\
\text { (mg/kg) }\end{array}$ & $\begin{array}{c}\text { Rubber's mistletoe leaf } \\
\text { (mg/kg) }\end{array}$ & $\begin{array}{c}\text { Orange's mistletoe leaf } \\
\text { (mg/kg) }\end{array}$ \\
\hline Macro & $\mathrm{Na}$ & $243.86 \pm 0.01$ & $157.63 \pm 0.03$ & $224.11 \pm 0.01$ \\
& $\mathrm{~K}$ & $265.74 \pm 0.02$ & $183.98 \pm 0.04$ & $217.86 \pm 0.02$ \\
& $\mathrm{Ca}$ & $428.35 \pm 0.03$ & $396.08 \pm 0.04$ & $422.7 \pm 0.03$ \\
& $\mathrm{Mg}$ & $586.91 \pm 0.01$ & $412.86 \pm 0.01$ & $566.95 \pm 0.01$ \\
\hline Micro & $\mathrm{Fe}$ & $501.20 \pm 0.00$ & $421.69 \pm 0.02$ & $525.38 \pm 0.01$ \\
& $\mathrm{Zn}$ & $321.68 \pm 0.03$ & $278.95 \pm 0.02$ & $315.76 \pm 0.02$ \\
& $\mathrm{Mn}$ & $79.82 \pm 0.03$ & $100.08 \pm 0.02$ & $58.25 \pm 0.04$ \\
\hline
\end{tabular}

Values are Mean \pm SEM.
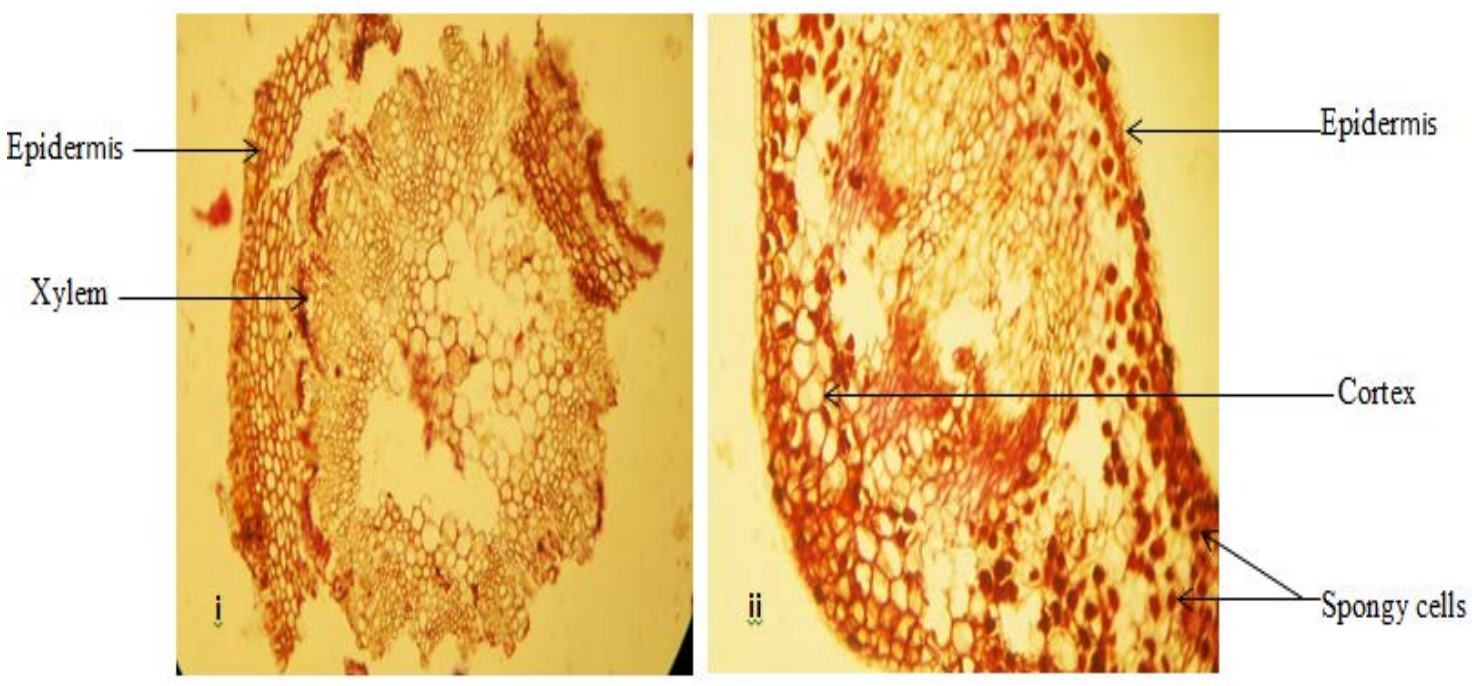

Figure 1. Cross Section of (i) stem and (ii) leaf of mistletoe from guava tree (x40).
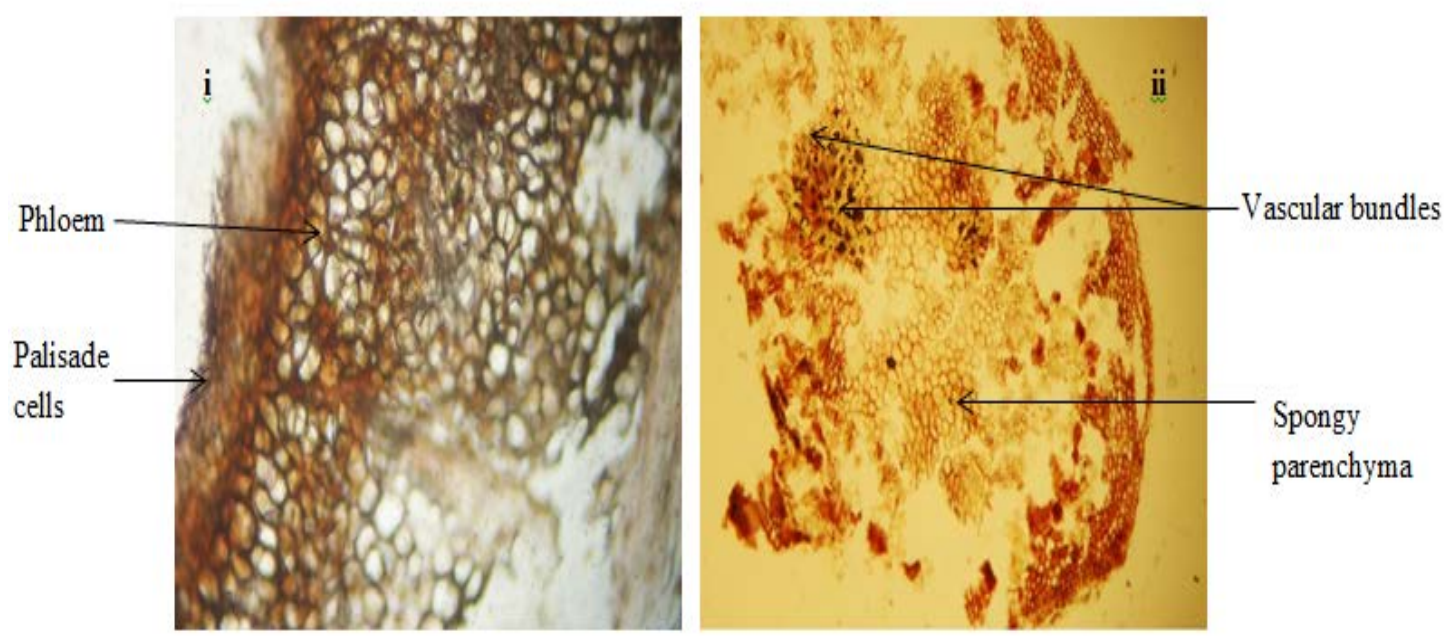

Figure 2. Cross Section of (i) leaf (x100) and (ii) stem of mistletoe from orange tree (x40). 


\section{Discussion}

Phytochemical screenings show the presence of oxalates phytate, saponin, alkaloid, glycoside and tannin in mistletoes harvested from all three plant hosts in varying levels (Tables 1 and 2). Oxalates are common constituent of plants. Studies have shown that oxalate can perform different roles in plants, including $\mathrm{Ca}$ regulation, ion balance, plant protection, tissue support and heavy metal detoxification (Rahman and Kawamura, 2011). Oxalate content found present in mistletoes harvested from guava $(18.74+$ $0.01)$, rubber $(210.65 \pm 0.03)$ and orange $(123.53 \pm 0.02)$ trees is an indication that an alternative source of $\mathrm{Ca}$ is needed by persons who consume these mistletoes very often to avoid developing health problems associated with high oxalate level in the body. A consumer having problems with any health conditions caused by oxalates kidney stones, autism or vulvodynia - then taking calcium citrate with each meal can be very effective (Shaw, 2010).

Phytate can also be known as inositol hexaphospate (IP6). IP6 or phytic acid when in salt form, is the principal storage form of phosphorus in many plant tissues especially grain and seeds. Phytate has been reported to have anticancer properties (Janab and Thompon, 2000). Phytate is not digestible to humans or nonruminant animals. However, it is not a source of either inositol or phosphate if eaten directly. Moreover it chelates thus making non-absorbable certain important minor minerals such as zinc and iron and to a lesser extent, also macro-mineral such as calcium and magnesium (Greiner et al., 2006). For an animal to utilize phytate molecule, an enzyme phytase must be present in the system. Simply cooking and soaking of phytate containing food would reduce its content (Vucenile and Shamsuddin, 2003). Therapeutic effects of phytates include broad-spectrum anticancer cocktail, boost immune system, help lower cholesterol, prevent kidney stones and the complications of diabetes, and reduce the risk of cardiovascular diseases, including heart attack, stroke etc.
Tanins have been reported to have an astringent and bitter taste (Okwu, 2005) and have been useful in reducing oxidative damage in human cells (Stephen et al., 2009). Tanins have also been reported to inhibit the growth of micro-organism by precipitating microbial protein and making nutritional proteins unavailable for them (Ogunleye and Ibitoye 2003). Tannins have also been implicated in the management of Diabetes (Kumari and Jain, 2012). It is therefore suggested that beside phytates, tanins may be an important factor responsible for low absorption of iron.

Saponins are well-known foamingagent, which have been said to have many pharmacological activities (Okwu, 2005). Saponins demonstrate antimicrobial properties particularly against fungi and additionally against bacteria and protozoa (Idu et al., 2013).

Glycoside is a molecule in which sugar is bound to non-carbohydrate molecule. Many plants store chemicals in the form of inactive glycoside. These can be activated by enzyme hydrolysis (BritoArias, 2007). However, flavonoid was not detected in any of the mistletoes found on rubber, orange and guava.

In this study, oxalate, phytate, saponin, alkaloid and glycoside are found in the result to be consistently high in the mistletoe from rubber than that of orange and guava (Table 1 and 2). This therefore suggests that the effects of these phytochemicals are more severe in the mistletoe found on the Rubber tree. The phytate content in mistletoes harvested from guava tree was observed to be as high as $285.31 \pm 0.03 \mathrm{mg} / 100 \mathrm{~g}$. This result corroborates with the findings of Malik et al. (2004). The oxalate and phytate contents of mistletoe on guava were also observed to be as $18.74 \pm 0.01$ and $285.31 \pm 0.03$ $\mathrm{mg} / 100$, respectively in this study. Though the type of host seems to influence the chemical components of the mistletoe but some mineral contents have been found to be absent or much higher in mistletoes than that in the host. This probably might be as a result of other environmental influence derived by mistletoe. This cannot be discussed with all certainty in that the hosts 
analyzed by Malik et al. (2004) might be free of infections or infected. Citrus and guava are very much edible due to the fact that their anti-nutritional capacity is minimal as a result of low phytate content and non-oxalate content. The variation metabolites had been observed by earlier workers (Deeni and Sadiq, 2002) where a dodoneifolius on eleven different hosts were screened for metabolites. The differences noted in the chemical constitutent of this parasite present on different hosts might justify why the host is as important as the parasite in pharmacognosy and why the use of this parasite in the treatment of an, ailment is usually dependent on a particular or specific host (Adodo, 2002; Olapade, 2002; Ibrahim et al., 2009).

Guava is rich in tanins, saponins, carotenoids, lectins, vitamins, fiber, fatty acids, triterpene, essential oil and flavonoid as well, and this confer upon it the antibacterial antioxidant and antispasmodiac activity which it possess (Arima and Danno, 2002).

Rubber in the Family

Euphorbiaceae is reputed for the production of valuable secondary metabolities such as alkaloid and flavonoid (Martin et al., 2002; Rani et al., 2002).

Orange and apple are rich in flavonoid carotenoids, saponins, and tanins these confer upon them the ability to reduce cardiovascular disease and cancer (Malik et al., 2004). The phytochemical analysis carried out during this study shows that flavonoid is absent in the mistletoes found on guava, orange and rubber. This therefore shows that metabolites of mistletoes are not only influenced by the host plants but environmental factors surrounding them.

The qualitative analysis in Table 2 shows that these phytochemicals are present in this mistletoe at different proportion. This might be due to their ability to utilize or store elements or chemicals provided by the environment. For instance if a plant has a high storage capacity for phosphorous, it therefore means that this plant would have high quantity of phytate since phytate is the storage form of phosphorous.
Table 3 shows the results of macro and micro-elements present in mistletoes harvested from guava, rubber and orange trees. Sodium and potassium are mineral elements that are important to the body. Sodium controls the fluid in the body and helps maintain the acid-base level. A sodium level in the blood that is too low is dangerous and can cause seizure and coma. Hyponatremia (low sodium level situation) can be corrected by increase in sodium level. Sodium and potassium initiates the electrolyte balance and this help to reduce diabetes and high blood pressure. Human needs as much $135-145 \mathrm{Mmol} / \mathrm{L}$ of $\mathrm{Na}$, 3.5$5.5 \mathrm{Mmol}$ of potassium, so a plant such as mistletoe rich in such elements could be a good source of these minerals if properly harnessed.

Iron has several vital functions in the body. It serves as a carrier of oxygen to the tissues from the lungs by red blood cell haemoglobin, as a transport medium for electrons within the cells and as an integrated part of important enzyme systems in various tissues. Men need as much as $10.6-28.3 \mu \mathrm{g} / \mathrm{L}$ while women need as much as $6.6-26.0 \mu \mathrm{g} / \mathrm{L}$. So, mistletoe which is rich in such element could be a good source of these minerals if properly harnessed.

Figures 1 and 2 which shows the microscopy of mistletoes leaf and stem collected from different host plants tells us that mistletoes are dicot plants as they have features such as cortex, vascular bundles, spongy parenchyma cells and palisade cells which are synonymous in dicot plants.

\section{Conclusion}

In conclusion, the phytochemical profile of mistletoes from the three host trees studied show that they contain similar phytochemical constituents although, present in varying concentrations. This may perhaps be due to their hemi-parasitic habit on their hosts and environmental factors. However, the pattern by which the hosts influence the hemi-parasite could not be ascertained in this study. The microscopic examination of the plant revealed important internal structures, which are beneficial in 
the plant identification. The microscopic result shows that there are no apparent differences between the species. Finally, high proportion of macro and micro elements were present in the plant. These elements, when properly harnessed can be a rich source of mineral nutrients for mankind.

\section{Conflict of interest statement}

Authors declare that they have no conflict of interests.

\section{References}

Adodo, A. Nature power: A Christian Approach to Herbal medicine. 3. ed. Ewu, Edo State: PAX Herbal Clinic and Research Laboratories, 2012.

Arima, H.; Danno, G. Isolation of antimicrobial compound from guava (Psidum guajava L.). Biotech Biochem., v. 66, p. 1727-1730, 2002.

Ataman, J. E.; Idu, M.; Odia, E. A.; Omogbai, E. K. I.; Amaechina, F.; Akhigbe, A. O.; Ebite, L. E. Histopathologic effects of Stachytarpheta jamaicensis (L.) Vahl. on wistar rats. Pakistan J. Biol. Sci., v. 9, p. 477-482, 2006.

Bhandari, J. B.; Mukhopadhyay, R. Morphological anatomical and phytochemical observations on two species of Vittaria smith. In: Maheshwari, J. K.; Jain, A. P. (Eds.). Recent researches in plant anatomy and morphology. Jodhpur: Scientific Publishers (India), 2001.

Brito-Arias, M. Synthesis and characterization of glycoside. New York: Springer, 2007.

Burger, A. M.; Mengs, U.; Schuler, J. B.; Fiebig, H. H. Anticancer activity of an aqueous mistletoe extract (AME) in syngeneic murine tumor models. Anticancer Res., v. 21, p. 19651968, 2001.

Cetin, E. S.; Ozcelik, N. Apoptotic mechanism of mistletoe (Viscum album) extract used in the treatment of cancer: review. Turk Klin Tip Bilim., v. 27, p. 533-539, 2007.

Cunniff, P. (Ed.). Official methods of analysis of Association of Official Analytical Chemist International. 18. ed. Mariland, USA: A.O.A.C., 2005.

Deeni, Y. Y.; Sadiq, N. M. Antimicrobial properties and phytochemical constituents of the leaves of African mistletoe (Tapinanthus dodoneifolius (DC) (Danser) (Loranthaceae): an ethnomedicinal plant of Hausaland, Northern Nigeria. J. Ethnopharmacol., v. 83, p. 235240, 2002.

Edeoga, H. O.; Eboka, A. U. Morphology of the leaf epidermis and systematic in some Dissotis Benth species (Melastomataceae). Global J. Pure and Applied Sci., v. 6, n. 3, p. 371-374, 2000.

Edeoga, H. O.; Ikem, C. I. Comparative morphology of leaf epidermis in three species of Boerhevia L. J. Econ. Tax. Bot., v. 19, p. 197205, 2001.

Ekhaise, F. O.; Ofoezie, V. G.; Enobakhare, D. A. Antibacterial properties and preliminary phytochemical analysis of methanolic extract of mistletoe (Tapinanthus bangwensis). Bayero $\mathbf{J}$. Pure Appl. Sci., v. 3, p. 65-68, 2010.

Greiner, R.; Konietzny, U.; Jany, K.-D. Phytate - an undesirable constituent of plant-based foods? Journal für Ernährungsmedizin, v. 8, p. 18-28, 2006.

Gupta, G.; Kazmi, I.; Afzal, M.; Rahman, M.; Saleem, S.; Ashraf, M. S.; Khusroo, M. J.; Nazeer, K.; Ahmed, S.; Mujeeb, M.; Ahmed, Z.; Anwar, F. Sedative, antiepileptic and antipsychotic effects of Viscum album L. (Loranthaceae) in mice and rats. J. Ethnopharmacol., v. 141, p. 810-816, 2012.

Hong, C. E.; Lyu, S. Y. The antimutagenic effect of mistletoe lectin (Viscum album L. var. coloratum agglutinin). Phytother. Res., v. 26, p. 787-790, 2012.

Ibrahim, A. L.; Ayodele, A. E.; Okhale, S. E.; Jegede, I. A.; Kunle, O. F. The taxonomic significance of the micromorphology/phytochemistry of Agelanthus dodoneifolius in relation to its hosts. Nig. $\mathbf{J}$. Bot., v. 22, p. 89-101, 2009.

Idu, M.; Erhabor, J.; Timothy, O.; OvuakporieUvo, O. Market survey and heavy metal screening of selected medicinal plants sold in some markets in Benin City, Nigeria. BEST: Intl. J. Humanities, Arts, Med. Sci., v. 2, p. 716, 2014.

Idu, M.; Gill, L. S.; Omonhinmin, C. A.; Ejale, A. Ethnomedicinal uses of trees among Bachama Tribe of Adamawa State, Nigeria. Indian J. Trad. Knowl., v. 5, p. 273-278, 2006. Idu, M.; Oshomoh, E. O.; Ovuakporie-Uvo, P. O. Phytochemistry and antimicrobial properties of Chlorophora excelsa, Cedrela odorata and Tectona grandis. Topclass J. Herbal Med., v. 2, p. 248-253. 
Jenab, M.; Thompson, L. U. Phytic acid in wheat bran affects colon morphology, cell differentiation and apoptosis. Carcinogenesis, v. 21, p. 1547-1552, 2000.

Judd, W. S.; Campbell, C. S.; Kellog, E. A.; Stevens, P. F.; Donaglue, M. J. Plant systematics: a phylogenetic approach. 2. ed. Sunderland: Sinaeur Associates, 2002. Availabe from: <http://donoghuelab.yale.edu/sites/ default/files/122_judd_2002_2nded.pdf $>$.

Accessed in: Jan. 23, 2016.

Kumari, M.; Jain, S. Tannins: An Antinutrient with positive effect to manage Diabetes. Res. J.

Recent Sci., v. 1, p. 70-73, 2012.

Lavastre, V.; Cavalli, H.; Ratthe, C.; Girard, D. Anti-inflammatory effect of Viscum album agglutinin-I (VAA-I): induction of apoptosis in activated neutrophils and inhibition of lipopolysaccharide-induced neutrophilic inflammation in vivo. Clin. Exp. Immunol., v. 137, p. 271-278, 2004.

Luczkiewicz, M.; Cisowski, W.; Kaiser, P., Ochocka, R.; Piotrowski, A. Comparative analysis of phenolic acids in mistletoe plants from various hosts. Acta. Pol. Pharm., v. 58, p. 373-379, 2001.

Malik, I. O.; Babiker, E. E.; Yousif, N. E.; El Tinay, A. H. In vitro availability of minerals of some tropical and citrus fruits as influenced by anti-nutritional factors. Food/Nahrung., v. 48, p.65-68. 2004.

Martin, A. P.; Salgueiro, L.-R.; Conclaves, M. J.; Vila, R.; Tomi, A. T.; Cunha, A. P.; Canigueral, S.; Casanova, J. Antimicrobial activity and chemical composition of bark oil of Croton stellulifier. Planta Medica, v. 66, p. 647-652, 2002.

Obadoni, B. O.; Ochuko, P. O. Phytochemical studies and comparative efficacy of the crude extracts of some homostatic plants in Edo and Delta States of Nigeria. Global J. Pure Applied Sci., v. 8, p. 203-208, 2001.

Ofem, O. E.; Eno, A. E.; Imoru, J.; Nkanu, E.; Unoh, F.; Bu, J. D. Effect of crude aqueous leaf extract of Viscum album (mistletoe) in hypertensive rats. Indian J. Pharmacol., v. 39, p. 15-19, 2007.

Ogunleye, D. S.; Ibitoye, S. F. Studies of antimicrobial activity and chemical constituents of Ximenia Americana. Tropical J. Pharm Res., v. 2, p. 239-241, 2003.

Okwu, D. E. Phytochemicals, vitamins and mineral contents of two Nigeria medicinal plants. J. Mol. Med. Adv. Sci., v. 1, p. 378-381, 2005.
Olapade, E. O. The herbs for good health: the 50th Anniversary Lecture of the University of Ibadan. Ibadan, Nigeria: NARL Specilist Clinic, 2002.

Orhan, D. D.; Aslan, M.; Sendogdu, N.; Ergun, F.; Yesilada, E. Evaluation of the hypoglycemic effect and antioxidant activity of three Viscum album subspecies (European mistletoe) in streptozotocin-diabetic rats. J. Ethnopharmacol., v. 98, p. 95-102, 2005.

Rahman, M. M.; Kawamura, O. Oxalate accumulation in forage plants: some agronomic, climatic and genetic aspects. Asian-Aust J. Anim. Sci., v. 24, p. 439-448, 2011.

Rani, S. S.; Murthy, K. S. R.; Pullaiah, T. Dye yielding Plants of Andhra Pradesh, India. J. Economic Taxonomic Bot., v. 26, p. 739-749, 2002.

Sabova, L.; Pilatova, M.; Szilagyi, K.; Sabo, R.; Mojzis, J. Cytotoxic effect of mistletoe (Viscum album L.) extract on jurkat cells and its interaction with doxorubicin. Phytother. Res., v. 24, p. 365-368, 2010.

Shahaboddin, M. E.; Pouramir, M.; Moghadamnia, A. A.; Lakzaei, M.; Mirhashemi, S. M.; Motallebi, M. Antihyperglycemic and antioxidant activity of Viscum album extract. African J. Pharm. Pharmacol., v. 5, p. 432436, 2011.

Shaw, W. The roles of oxalates in autism and chronic disorders. The Weston A, Price Foundation for wise traditions in food, farming and the healing arts. U.S.A., 2010. Available from: <http://www.sott.net/articles/show/ 215309-The-Role-ofOxalates-in-Autism-andchronic-Disorders>. Accessed in: Jan. 23, 2016.

Sofowora, E. A. Medicinal plants and traditional medicine in Africa. Nigeria: John Wiley and Sons Ltd., 2008.

Stephen, U. A.; Abiodun, F.; Osahon, O.; Ewaen, E. Phytochemicalanalysis and antibacterial activity of Khaya grandifolia stem bark. J. Biol. Sci., v. 9, p. 63-67, 2009.

Tenorio-Lopez, F. A.; Del Valle, L.; Gonzalez, A.; Pastelin, G. Vasodilator activity of the aqueous extract of Viscum album. Fitoterapia, v. 76, p. 204-209, 2005.

Tenorio-Lopez, F. A.; Mondragon, L. D.; Olvera, G.Z.; Narvaez, J.C.T.; Pastelin, G. Viscum album aqueous extract induces NOS-2 and NOS-3 over-expression in Guinea pig hearts. Nat. Prod. Res., v. 20, p. 1176-1182, 2006. 
Uthman, G. S.; Bika, S. N.; Timothy, S. Y. Anticonvulsant screening of the methanolic leaf extract of Tapinanthus dodoneifolius Danser (Loranthaceae) in pentylenetetrazole induced seizure model in albino rats. International Journal of Pharma and Bio Sciences, v. 6, p. 245-250, 2015.

Vicas, S. I.; Rugina, D.; Leopold, L.; Pintea, A.; Socaciu, C. HPLC fingerprint of bioactive compounds and antioxidant activities of Viscum album from different host trees. Not Bot Horti Agrobot Cluj-Napoca, v. 39, p. 48-57, 2011.

Vucenik, I.; Shamsuddin, A.M. Cancer inhibition by inositol hexaphosphate ( $\left.\mathrm{IP}_{6}\right)$ and inositol: from laboratory to clinic. J. Nutr., v. 133, p. 3778S-3784S, 2003.

License information: This is an open-access article distributed under the terms of the Creative Commons Attribution License, which permits unrestricted use, distribution, and reproduction in any medium, provided the original work is properly cited. 